\title{
PROFESORA VOLDEMĀRA GRĪNŠTEINA IEGULDĪJUMS SINTĒTISKO ĀRSTNIECĪBAS PREPARĀTU RADĪŠANĀ
}

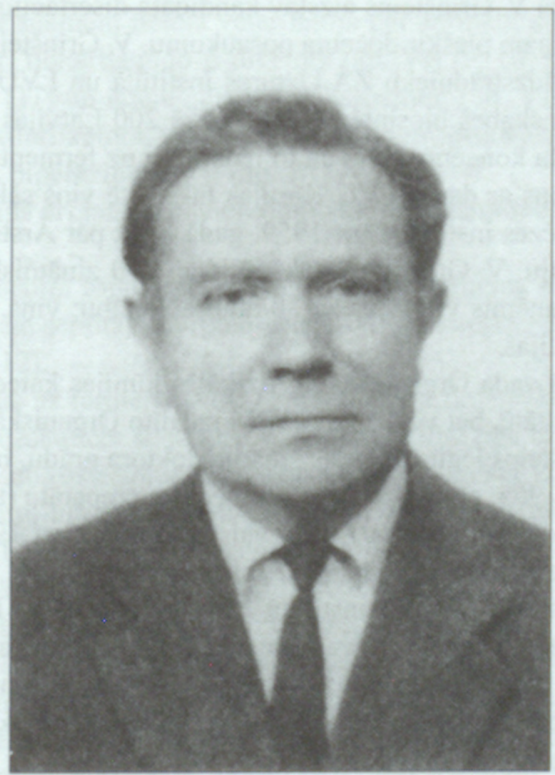

Voldemārs Grīnšteins (1911-1985)

Apskats par profesora V. Grīnšteina dzīvi un darbību publicēts viṇa pēdējās jubilejas (70 dzīves gadu slieksni pārkāpjot) personālajā literatūras rādītājā [1]. Taču viṇš pềc tam vēl ražīgi darbojās atlikušos mūža gadus, tāpēc publicēto darbu, autorapliecību u.c. skaits ir krietni lielāks; tas precizēts viņa nekrologā [2].

Voldemārs Grīnšteins dzimis 1911. g. 14. jülijā Tukuma apriņ̧̧a Grenču pagastā. 1930. gadā viṇš beidz Tukuma reālǵimnāziju un iestājas LU K̦īmijas fakultātē, bet pềc tās teorijas noda|as beigšanas 1936. gadā uzsāk patstāvīgu darbu V. Lejnieka privātajā farmaceitiskajā laboratorijā, kur piedalās adrenalīnu un kodeīnu saturošu preparātu sintezēšanā, tādējādi sākot darbu ar fiziologiski aktîviem savienojumiem. 
1939. gadā V. Grīnšteins sāk strādāt Lauksaimniecības akadēmijā prof. Kārla Bamberga (1894-1981) vadītajā Lauksaimniecības k̦īmijas katedrā. 1946. gadā kopā ar K. Bambergu izdod mācību grāmatu Kvantitativiã analīze [3], kas pēckara periodā klūst par vērtīgu mācību līdzekli latviešu valodā topošajiem agroḳimiķiem, kā arī neorganiskās analīzes un bioḳīmijas jomã strādājošajiem speciālistiem.

1941. gadā V. Grīnšteins sāk strādāt LU Ķīmijas fakultātē pie prof. A. Ieviṇa par subasistentu, vēlāk par asistentu. Viṇu arvien vairāk ieinteresē biologijjas zinātne, it īpaši botānika un augu anatomija. V. Grīnšteins pašmācības ce|ā apgūst speciālo literatūru un botāniķa darba paṇēmienus. 1943. gadā viṇš sāk strādāt prof. Kār|a Ābeles (1896-1961) vadībā Dabaszinātñu fakultātes Augu anatomijas katedrā par asistentu. 1948. gadā V. Grīnšteins aizstāv kandidāta disertāciju; 1950. gadā LVU Ḳīmijas fakultāte viṇam piešķir docenta nosaukumu. V. Grīnšteins strādājis arī par vecāko zinātnisko līdzstrādnieku ZA Uztures institūtā un LVU Biologijas fakultātē. Pētījis askorbīnskābes biosintēzi vairāk nekā 200 Latvijas gladiolu šķirnēm, kā arī ievas fitoncīdu koncentrēšanu un to iedarbību uz fermentiem.

1957. gadā vienlaikus ar darbu LVU Kịimijas fakultātē viṇš sāk strādāt arī LPSR ZA Organiskās sintēzes institūtā, kur 1959. gadā klūst par Ārstniecības vielu sintẽzes sektora vadītāju. V. Grīnšteins publicējis ap 170 zinātnisku un 30 populārzinātnisku darbu, saṇēmis vairāk nekā 30 autorapliecību; viṇa vadībā izstrādātas 8 kandidāta disertācijas.

No 1964. gada viņš vada Organiskãs un fizikālās ķīmijas katedru LVU jaundibinātajā Ķīmijas fakultātē, bet vēlāk - atsevišķi izdalīto Organiskās k̦īmijas katedru. 1966. gadā V. Grīnšteins iegūst ḳīmijas zinātṇu doktora grādu, bet 1969. gadā profesora nosaukumu. 1965. gadā par jaunu ārstniecības preparātu (transamīna, ciazīda u.c.) izstrādāšanu viṇam piešḳirta LPSR Valsts prēmija, bet 1971. gadā - LPSR Nopelniem bagātā zinātnes un tehnikas darbinieka nosaukums.

Strādājot ZA Organiskās sintēzes institūtã (no 1957. gada) un klūstot 1959. gadā par Ārstniecības vielu kịmijas laboratorijas vadītāju, profesora V. Grīnšteina vadībā izpētīta jaunu tuberkulostatisko preparātu un antidepresantu iegūšana, sintezēti un izpētīti visdažādākie aliciklisko, aromātisko un heterociklisko savienojumu amīnu, hidrazīnu, guanidīnu un tiokarbamīdu atvasinājumi.

Uzlabota metode arilciklopropilamīnu sintēzei un to cisizomēru un trans izomēru atdalī̌sanai [4].

Konstatēts, ka 2-fenil-, 2-p-metoksifenil- un 2- (1, 2, 3, 4- tetrahidro naftil- 6) ciklopropilamīni ir visaktīvākie fermenta monoaminooksidāzes inhibitori. No tiem klīniskajā praksē izpētīts transamīns (att. I) [5, 6].

Transamīns (trans-d-1-2-fenilciklopropilamīna sērskābā sāls) minimālā koncentrācijā kavē fermenta monoaminoksidāzes darbību; to lieto kā antidepresantu dažu psihisko slimību ãrstēšanā.

Veikta $\alpha$-aminometilderivātu sintēze un sistemātiska izpēte kondensēto aromātisko un heteroaromātisko savienojumu rindā ar kopējo formulu (att. II), kas ir jauna antidepresantu klase. II formulā ar $\mathrm{R}$ apzìmēti naftalīna, tetrahidronaftalīna, 
antracēna, fenantrēna, hinolīna, akridīna, kā arī dibenzfurāna atlikumi dažādās to pozīcijās [7]. Sintezēti un izpētīti benzilamīna atvasinājumi (att. III), kam konstatēta augsta anti-MAO aktivitāte [8].

Sistemātiski pētījumi veikti, sintezējot ciānkarbonskābju un oksiskābju hidrozīdus, hidrazonus un tioamīdus (att. V). Daudziem savienojumiem noskaidrota sakarība starp to kెimisko uzbūvi un tuberkulostatisko un anti-MAO aktivitāti. No tiem visaktīvākais tuberkulostatiskais preparāts izrādījies ciazīds (ciānetik̨skābes hidrazīds) (att. IV), kas pirmoreiz iegūts 19. gadsimta beigās. No 1959. gada ciazīda un tā atvasinājumu tuberkulostatisko un antidepresanta iedarbība sistemātiski pētīta V. Grīnšteina vadībā; 1964. gadā tas ieviests medicīnas praksē acu tuberkulozes dziedināšanai, jo ir maz toksisks, nekairina acs konjunktīvu, to labi panes bērni. Bez tam ciazīdu ar sekmēm lietoja veterinārijā par antihelmintu.

Pirmoreiz iegūti arī tiokarbamīdo- $\beta$-diketoni (att. VI) $[9,10]$ kā arī tiokarbamīdoaldehīdi (att. VII) [11] un ūdenī šḳistoši tiokarbamīdi (att. VIII). Sintezēti dažādi $\alpha-, \beta$-, $\gamma$-aminoalkilarilketoni, kuriem piemīt psihotropiska aktivitāte; no tiem visaktīvākie izrādījās piperazinoketoni (att. IX).

V. Grīnšteins atklājis arī jaunas savienojumu klases guanidīno- $\beta$-diketonu ieguves metodi.

Par MAO aktīvā centra topoḳimsko uzbūvi un šã fermenta darbības mehānismu V. Grīnšteins referēja septītajā starptautiskajā IUPAC simpozijā, kas bija veltīts dabasvielu k̦īmijai. [12].

Substrāts iedarbojas uz fermenta MAO aktīvā centra flavīna komponentu (att. X). Pēc V. Grīnšteina uzskatiem substratiem līdzīgie amīnu tipa inhibitori, kã arī policikliskie slāpekli saturošie inhibitori iedarbojas uz flavīna komponentu vienādi. Korelācija starp pargilīna un citu benzilamīna atvasinājumu, kā arī kondensētu sistêmu un heterociklisko bāzu aminosavienojumu struktūru un MAO inhibitoru iedarbību parādīja, ka MAO aktīvajā centrā bez flavīna pastāv fermenta katalitiskajai aktivitātei loti nepieciešamais atomu grupējums A.

Pēc fermenta aktīvā centra elektrofilā grupējuma A uzbrukuma slāpek|a nedalītajam elektronu pārim inhibitors orientējas tā, lai dotajos telpiskajos apstāklos veidotos maksimāla mijiedarbība starp inhibitora molekulas un MAO kofermenta izoaloksazīna da|as savstarpēji saskarošajām komplementārajām virsmām.

Vairākums Grīnšteina pētīto MAO inhibitoru uzbrūk tikai fermenta aktīvã centra elektrofilajai grupai A. Dažu bifunkcionālu inhibitoru, piemēram, pargilīna piesaistī̌anai, svarīga nozīme ir arī MAO aktīvã centra nukleofilajam grupējumam B. Nosakot atomu grupējumu A un B orientējošo topogrāfiju, secināts, ka grupējums A atrodas apmēram 2-3 $\AA$ attālumā no izoaloksazīna gredzena 3. un 4. atoma. Attālums starp A un B ir aptuveni 5 Å. Pieñem, ka centrs B atrodas flavīna izoaloksazīna 10. atomā, bet centrā $\mathrm{A}$ visticamāk atrodas varš $(\mathrm{Cu}+$ ? $)$.

Par galvenajiem pētijjumiem, kas veikti V. Grīnšteina virsvadībā LU Organiskās k̦īmijas katedrā, gadu pēc V. Grīnšteina pēkšñās nāves (1985. g. 4. septembrī) publicēts apkopojums [13] 


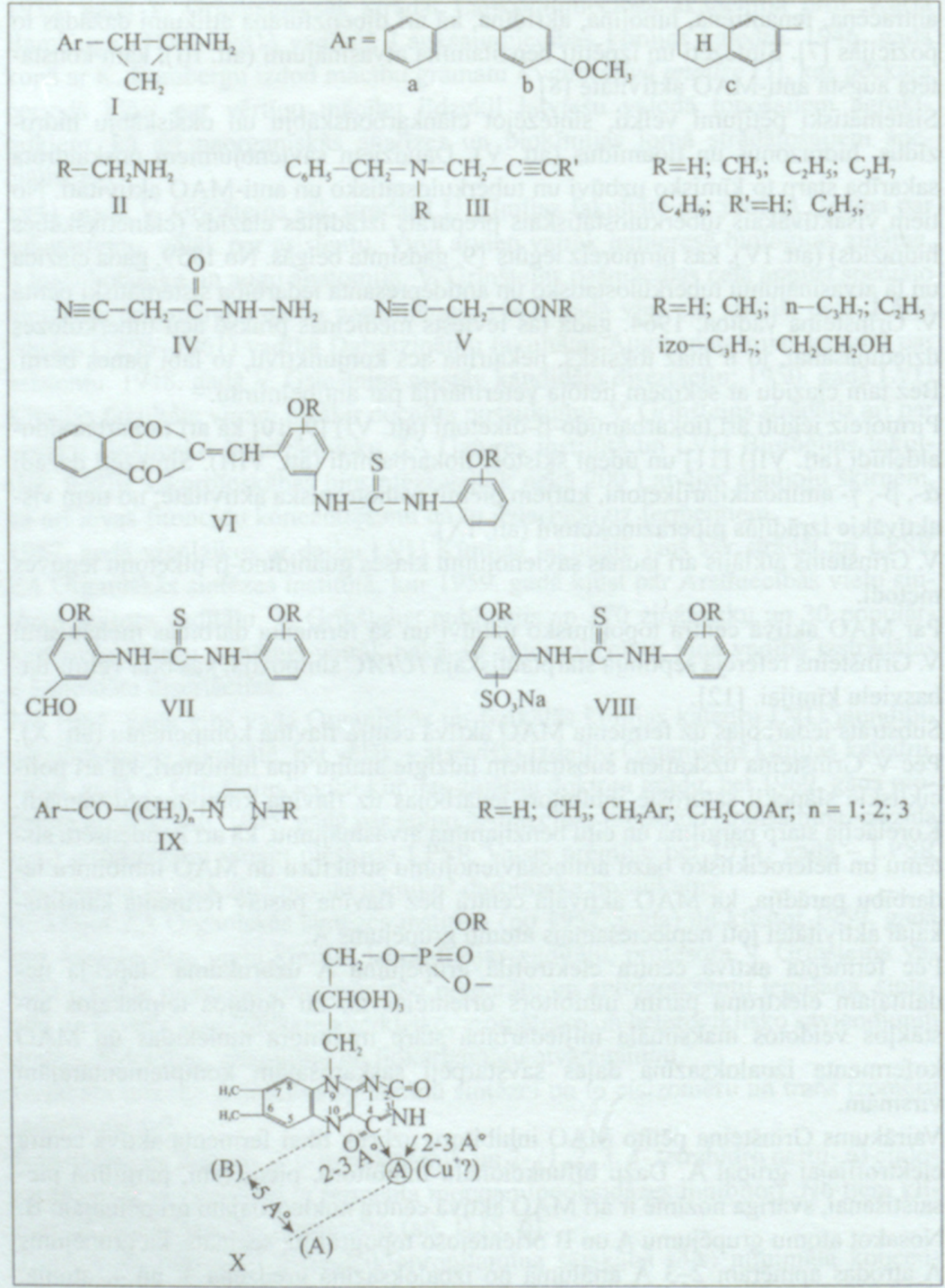

Tekstā minēto ķīmisko savienojumu formulas:

I aminociklopropāna atvasinājumi; II, III benzilamīna derivāti; IV, V ciānetiķskābes atvasinājumi; VI, VII, VIII tiokarbamīda derivāti; IX piperazīnketoni; X monoaminooksidāzes aktīvā centra flavīna komponents 
Profesoram V. Grīnšteinam bija neparasti plašs zināšanu un interešu loks, viṇš bija loti principiāls, nelaipoja, nepie|āva kompromisus, bija prasīgs pret studentiem un katedras kolektīvu, bet tajā pašā laikā arī dzili iejūtīgs un izpalīdzīgs. Tāds profesors Voldemārs Grīnšteins paliks mūsu piemināā.

\section{Literatūra}

1. Dumpis T. Kīmijas zinātṇu doktors, profesors Voldemārs Grīnšteins // Profesors Voldemārs Grīnšteins: Personālais literatūras rādītājs P. Stučkas LVU. - Rīga, 1981. 7.-19. Ipp. (latviešu un krievu valodā).

2. Dumpis T. Profesoru Voldemāru Grīnšteinu pieminot // Padomju students. - Rīga, 1985. 17. novembrī, Nr. 5 (1547). -4 . Ipp.

3. Bambergs K., Grīnšteins V. Kvantitatīvã analīze. - Rīga: Latvijas Valsts izdevniecỉba, 1946.

4. Бауманис Э.А., Гринитейн В.Я., Фрейманис Т.Х., Орвид З.Ж. Сравнительное изучение влияния транс-2-фенилциклопропиламина (трансамина) и фенамина на ферментативную активность моноаминоксидазы // Изв. АН Латв. ССР. Серия хим. - 1962. - № 4. - С. 563-569.

5. Гринштейн В.Я., Ратенберг Н.С., Морозова Т.Н. Данные экспериментального и клинического изучения нового ингибитора моноаминоксидазы - трансамина // Журнал невропатологии и психиатрии им. С.С. Корсакова. - 1962. - Т. 62, вып. 12. C. $1806-1812$.

6. Трансамин (Transaminum): Инструкция по применению препарата. - Рига: Изд-во АН Латв. ССР, 1964.

7. Гринштейн В.Я., Вина И.А., Мелдрая М.Я. Синтез и изучение потенциальных антидепрессантов: Синтез и биохимическое изучение некоторых $\omega$-аминометилпроизводньг конденсированньг ароматических и гетероциклических соединений // Изв. АН Латв. ССР. - 1967, - № 7. - С. 128-136.

8. Гринитейн В.Я. Синтез и изучение новых амино-, гидразино- и гуанидинопроизводных ароматического рядас потенциальным противотуберкулезным и антидепрессивным действием // Обобщающий доклад по научн. работам, представл. на соискание учен. степени д-рахим. наук. - Рига, 1966. - С. 1-63.

9. Гринитейн В.Я., Веверис А.П. Гуанидино- $\beta$-дикетоны [Сообщ.]: 1. Синтез и свойства некоторых амино- и гуанидино- $\beta$-дикетонов с группировкой $\beta$-дикетонов в открытой цепи // Изв. АН Латв. ССР Серия хим. - 1962. - №. 3. - С. 463-471.

10. Гринитейн В.Я., Ванаг Э.В. Гуанидино- $\beta$-дикетоны. [Сообщ.]: 2. 2-гуанидино-2замещенные индандионы-1,3. // Изв. АН Латв. ССР. Серия хим. - 1962. - №. 4. C. 513-518.

11. Веверис А.П., Гринштейн В.Я. Способ получения ароматических производных n-гуанидиноальдегидов // Авт. свидетельство № 172307 (приоритет от 10 июля 1964). - Там же. - № 13. - С. 17.

12. Гринитейн В.Я., Вина И.А. О топохимическом строении активного центрамитохондриальных моноаминоксидаз (МАО) и механизма действия фермента // 7-й Международный симпозиум по химии природных соединений, Рига, 21-27 июня 1970 г.: Тезисы докл. - Рига, 1970. - С. 174-175.

13. Дрегерис Я.Я., Прикулис А.А., Думпис Т.Т., Жагарс А.Х, Кастрон Я.А. Основные направления научно-исследовательской работы кафедры органической химии Химического факультета ЛГУ им. П. Стучки // Изв. АН Латв. ССР. Серия химическая. - 1986. - № 4. - С. 387-397. 


\section{Professor Voldemãrs Grīnšteins Contribution into Creation of Synthetic Medical Preparations (summary) \\ By Teodors Dumpis}

The article is dedicated to Voldemārs Grīnšteins (1911-1985) life and work. His contribution into the synthesis of new physiologically active compounds is connected with obtaining new anti-tuberculosis preparations (cyazid - cyano acetic acid hydrazid and others) and their instilling into production. The inhibitors of monoaminooxidase ferment that showed antidepressant properties (transamine and others) have been explored by V. Grīnšteins. The method for obtaining new type of organic combinations - guanidino- $\beta$-diketones was discovered by him. V. Grīnšteins was awarded the state prize of Latvian Soviet Socialistic Republic in 1965 for elaborating and instilling into production new medical preparations.

Teodors Dumpis, Dr. chem.

Paula Stradina Medicīnas vēstures muzejs

Antonijas 1. Rīga, LV-1360, Latvija

E-mail: museum2@apollo.lv 